\title{
ANALISIS PERGERAKAN KERETA REL LISTRIK UNTUK DISAIN SISTEM KESELAMATAN KERETA API OTOMATIS ANALYSIS OF ELECTRIC RAIL TRAIN MOVEMENTS
FOR AUTOMATIC TRAIN PROTECTION SYSTEM DESIGN
}

\author{
Syamsul Kamar \\ Pusat Teknologi Industri dan Sistem Transportasi \\ Deputi Teknologi Industri Rancang Bangun dan Rekayasa - BPPT \\ Gedung Teknologi 2 (251) Lantai 3 Komplek PUSPIPTEK Serpong, Tangerang Selatan 15314 \\ Telp: 021-75875943; Facs. 021-75875946 \\ e-mail: syamsul.kamar@bppt.go.id
}

\begin{abstract}
Abstrak
Beberapa penelitian menunjukkan bahwa penyebab kecelakaan kereta api di Indonesia di dominasi antara lain kesalahan manusia (human error) berupa ketidak disiplinan pengguna jalan, tidak adanya palang pintu di beberapa lintasan kereta api, dan adanya kelalaian masinis. Untuk meminimalkan kecelakaan kereta api akibat hal-hal tersebut, khususnya akibat kesalahan masinis komuterline di Jakarta-Bogor-Depok-Tangerang-Bekasi (JABODETABEK), perlu dipertimbangkan penggunaan "Sistem Keselamatan Kereta Api Otomatis (SKKO)".yang secara internasional dikenal sebagai automatic train protection (ATP).

ATP sebagai sistem kendali otomatis membutuhkan pengembangan perangkat lunak (software) yang mengatur tampilan MMI (Man-Machine-Interface), kendali otomatis untuk mengatur kecepatan kereta. Untuk membangun software tersebut beberapa hal perlu mendapat perhatian antara lain kondisi lintasan, track, akselerasi kereta, dan deselerasi pengereman. Berdasarkan hal tersebut telah dianalisis hal-hal yang dibutuhkan untuk desain sistem keselamatan kereta api otomatis khususnya untuk penerapan pada komuterline seperti jaringan komuter line di Jakarta-Bogor-Depok-Tangerang-Bekasi (JABODETABEK), yang menggunakan kereta rel listrik (KRL), yaitu kondisi lintasan (track) terutama berkaitan dengan panjang blok, besarnya headway, dan lain-lain, akselerasi masing-masing KRL yang melayani lintasan bisa diperoleh dari hasil uji dinamis, deselerasi pengereman dinamis (dynamic braking), pengereman pneumatik (pneumatic braking), pengereman darurat (emergency braking) masing-masing KRL yang melayani lintasan yang bisa diperoleh dari hasil uji dinamis.

Hasil analisa tersebut menunjukkan bahwa hasil uji dinamis KRL berupa akselerasi masing-masing KRL, deselerasi pengereman dinamis, deselerasi pengereman pneumatik, deselerasi pengereman darurat dapat bermanfaat dalam mengembangkan algoritma untuk merancang system kendali kereta sedemikian rupa sehingga kecelakaan akibat kesalahan masinis dapat diminimalkan
\end{abstract}

Kata Kunci : desain ATP, uji dinamis, kereta rel listrik.

\begin{abstract}
Resulte of research suggest that the cause of train accident in Indonesia is dominated by human error in the form of indiscipline road users, the absence of a doorstop at some railroad tracks, and negligence of the drivers. To minimize the train crash as a result of these matters, in particular due to errors of commuterline machinist in Jakarta-Bogor-Depok-Tangerang-Bekasi (Jabodetabek), it is required to consider use of the"Automatic Train Safety System (SKKO)", which is internationally known as Automatic Train Protection (ATP).

The automatic control system requires development of software that regulatesdisplay of the $\mathrm{MMI}$ (Man-Machine-Interface), automatic control to
\end{abstract}


manage speed of the train and others. In order to develop the software, a few thing need attention, among others, track conditions, train acceleration, deceleration braking. It has been analyzed parameters needed for the design of automated train safety systems, especially for application in commuter-line as a commuter line network in the Jakarta-Bogor-Depok-Tangerang-Bekasi (Jabodetabek), which is used by electric train (KRL), namely the condition of the trackwhich is primarily concerned with the length of the block, the amount of headway, and others. Acceleration KRL seres trajectory that can be obtained from the results of the dynamic test, dynamic braking deceleration, pneumatic braking, emergency braking which can be obtained from the test.

Results of the analysis showed that the KRL dynamic test results, namely the acceleration of each KRL, dynamic braking deceleration, deceleration pneumatic braking, emergency braking deceleration can be useful to develop algorithms to design the train control system in such away that accidents caused by the negligence of the drivers can be minimized.

Keywords : automatic train protection (ATP), the dynamic test, electric train

Diterima (recieved) : 13 Juni 2015, Direvisi (Revised) : 23 Juli 2015, Disetujui (Accepted) : 27 Juli 2015

\section{PENDAHULUAN}

Beberapa penelitian menunjukkan bahwa penyebab kecelakaan kereta api di Indonesia di dominasi antara lain kesalahan manusia (human error). Kelalaian manusia tersebut antara lain berupa ketidak disiplinan pengguna jalan, tidak adanya palang pintu di beberapa lintasan kereta api, dan adanya kelalaian masinis.

Untuk meminimalkan kecelakaan kereta api akibat hal-hal tersebut, khususnya akibat kesalahan masinis, beberapa teknologi sederhana telah diperkenalkan antara lain dengan deadman pedal. Dalam lokomotif, dipasang deadman pedal yang diinjak dan diangkat secara bergantian oleh masinis. Apabila proses injak-angkat tak dilakukan karena masinis mengantuk atau tertidur, alarm akan berbunyi dan lokomotif akan berhenti.

Negara maju seperti negara-negara di Eropa, Amerika, Jepang dan Australia, dikembangkan dan diterapkan sistem pengamanan kereta menggunakan automatic train protection (ATP), yang dirancang untuk operasi failsafe kereta. Tugas dasar ATP adalah mengatur secara otomatis kecepatan kereta berdasarkan situasi lalu lintas dan reaksi masinis.

Alasan utama lain adalah mendorong penerapan ATP sesuai kebutuhan untuk meningkatkan kecepatan kereta dimana pada kecepatan tersebut manusia (masinis) tidak dapat bereaksi dengan baik mengendalikan kereta menggunakan sinyal konvensional dengan cara yang aman. Pada penerapan ATP tersebut, pengemudi (masinis) tetap berfungsi sebagai operator dimana semua tindakannya di bawah pengawasan dari sistem ATP,

Di Indonesia, Direktorat Jendral Perkereta Apian sejak tahun 2012 mulai memperkenalkan dan merencanakan penggunaan sistem ATP untuk keselamatan perkeretaapian.

Pada dasarnya sistem ATP yang dikombinasikan dengan pengaturan blok jalan rel bukanlah sistem tunggal, melainkan gabungan dua sistem besar yaitu, sistem yang dipasang di atas kereta dan sistem yang dipasang pada pusat kendali. Sistem yang dipasang di atas kereta terdiri atas beberapa sub sistem yaitu (1) Sub sistem pendeteksi keadaan kereta, seperti posisi, kecepatan dan integritas kereta api; (2) subsistem ATP, yang digunakan untuk mengevaluasi kecepatan dan akan mengambil tindakan yang tepat jika beberapa situasi tertentu terjadi seperti kelalaian atau kesalahan operasi masinis, gempa bumi, dan kereta api terputus, (3) subsistem komunikasi, yang digunakan untuk mengirim dan menerima pesan dan perintah ke dan dari pusat kendali; dan (4) sistem pencatatan. Sedangkan pusat kendali terdiri atas, (1) sub sistem komunikasi, yang digunakan untuk mengirim dan menerima perintah dan pesan ke dan dari kereta api; (2) sub sistem interlock, yang bertanggung jawab untuk setpoin, dan penetapan jalur berdasarkan informasi yang diterima dari kereta, (3) manajemen operasi lalu lintas.

Untuk mendukung penerapan sistem ATP tersebut, di Indonesia, dilakukan kajian yang bertujuan untuk mengembangkan perangkat komponen sistem kendali ATP dalam rangka meningkatkan derajat keselamatan pengoperasian kereta api dengan mencegah 
terjadinya tabrakan kereta dengan kereta, pembatasan kecepatan kereta yang berjalan melebihi batas kecepatan, antisipasi terjadinya anjlok (derailment) kereta, mendeteksi fasilitas keamanan dan perlindungan bagi pekerja dan peralatan yang ada di lapangan.

\section{BAHAN DAN METODE}

\section{Prisnsip Kerja ATP}

ATP adalah suatu sistem keamanan kereta api yang merelai informasi aspek sinyal, informasi batas kecepatan pada lintasan (block) tertentu, dan informasi lain tentang block tersebut ke sistem kendali yang dipasang dalam kabin kereta atau lokomotif, dan dapat secara otomatis memberi peringatan pada masinis, memperlambat laju atau menghentikan laju kereta tersebut, sebelum kereta memasuki kondisi berbahaya, seperti apabila melebihi kecepatan yang diizinkan atau memasuki wilayah sinyal muka dengan kecepatan yang relative tinggi ${ }^{1,2)}$.

Berdasarkan hal tersebut, maka sistem ATP dibagi menjadi 3 bagian, yaitu

a. Bagian Stasioner (stationary part) minus sistem komunikasi jarak jauh.

b. Bagian Bergerak (mobile part) minus sistem komunikasi jarak jauh.

c. Sistem Komunikasi Jarak Jauh.

Bagian stasioner adalah peralatan yang ditempatkan di stasiun kereta yang berfungsi menyediakan beberapa informasi yang akan dikirim baik melalui udara maupun melalui kabel, ke sistem kendali yang ada di kabin kereta atau lokomotif. Bagian Stasioner ini terdiri atas komponen antara lain:

a. Informasi aspek sinyal, termasuk berapa jauh kereta dapat berjalan;

b. Jarak kereta ke lokasi papan sinyal didepannya.

c. Batas kecepatan pada blok;

d. Kemiringan track;

e. Wilayah yang tidak boleh berhenti; dan

f. Perlintasan sebidang.

Bagian bergerak yaitu perangkat yang ditempatkan pada kabin kereta atau lokomotif terdiri atas :

a. Man-Machine-Interface (MMI) yang berfungsi menampilkan informasi yang perlu diketahui oleh masinis;

b. Sistem kendali yang mengatur secara otomatis kecepatan kereta; dan

c. Sistem komunikasi

Berdasarkan bentuk transmisi data dari bagian stasioner ke bagian bergerak (mobile part), maka ATP dapat dibedakan atas dua macam yaitu : a. ATP Intermitten, yaitu sistem ATP di mana informasi dari bagian stasioner yang disediakan untuk kereta hanya disediakan di lokasi tertentu (biasanya dengan transponder atau balise tetap di lintasan), sehingga jika kereta berada di antara dua lokasi tersebut, kereta tidak dapat menerima update perubahan informasi. Kondisi ini, seperti pada keadaan sinyal berubah dari sinyal berhenti (merah) ke sinyal melanjutkan (kuning atau hijau), informasi tersebut tidak dapat segera disampaikan ke kereta, sampai kereta mencapai balise berikutnya.

Program operasional sistem ATP intermitten memiliki tiga fungsi yaitu;

(1) sistem peringatan otomatis;

(2) kurva pengawasan pengereman, dan

(3) memberhentikan kereta.

Tempat-tempat pengiriman data dari bagian stasioner diusahakan pada semua titik yang memerlukan pembatasan kecepatan kereta (untuk kereta berhenti) dimana tempat tersebut adalah berjarak aman sesuai dengan kurva pengereman dari tempat sinyal pemberhentian yang ada di depannya.

Cara kerja sistem adalah, ketika kereta melintasi tempat pengiriman data, seperti balise, dan balise tersebut memberikan indikasi harus berhenti di depan sinyal, maka sistem peringatan otomatis ditransmisikan ke bagian bergerak di kereta. Jika masinis tidak melakukan pengaturan kecepatan sesuai dengan kurva pengawasan pengereman yang disediakan, maka ATP secara otomatis melakukan pengereman.

b. ATP Kontinyu, adalah sistem ATP yang lebih signifikan dalam hal kinerja di banding sistem ATP intermitten, tapi sangat mahal, terutama peralatan lintasan kereta. Sistem kontinyu berarti data ditransmisikan secara terus menerus antara peralatan lineside dan kereta. Kereta menerima data setiap saat untuk mengontrol sistem proteksi. Batas kecepatan kereta diawasi terus menerus. Dalam beberapa sistem, seluruh trek dilengkapi dengan sistem transmisi. Dalam sistem lain, pemasangan sistem transmisi terbatas untuk melacak bagian transmisi data yang diperlukan dalam rangka mengawasi kecepatan kereta. Suatu ATP terus menerus selalu dikombinasikan dengan sinyal kabin dimana kondisi trek yang biasnya dibaca melalui peralatan persinyalan disamping rel, ditampilkan di dalam kabin masinis. Pada lintasan di mana semua kereta 
dilengkapi dengan ATP kontinyu, maka persinyalan konvensional tidak dibutuhkan lagi ${ }^{3}$.

\section{Pergerakan Kereta untuk Desain ATP}

Dengan pesatnya perkembangan kebutuhan layanan kereta api, faktor keselamatan transportasi kereta api juga memerlukan perhatian yang lebih tinggi. ATP sebagai sistem keselamatan kereta api memainkan peran penting dalam masalah keamanan sistem kereta api modern, di mana fungsi, algoritma dan alat komunikasinya bervariasi secara dramatis dengan perubahan lingkungan aplikasi.

Sebagaimana disebutkan sebelumnya bahwa salah satu alasan mendorong penerapan ATP adalah kebutuhan untuk meningkatkan kecepatan kereta di mana pada kecepatan tersebut manusia (masinis) tidak dapat bereaksi dengan baik mengendalikan kereta menggunakan sinyal konvensional dengan cara yang aman ${ }^{4)}$. Kereta komuter seperti Kereta Rel Listrik $(\mathrm{KRL})$ yang melayani kebutuhan jasa angkutan massal di Jakarta dan sekitarnya tidak memerlukan kecepatan yang tinggi sampai $200 \mathrm{~km} / \mathrm{jam}$, akan tetapi KRL tersebut mampu dipacu sampai kecepatan 100 $\mathrm{km} / \mathrm{jam}$ bahkan lebih, sementara jarak antara stasiun pemberhentian ke stasiun pemberhetian berikutnya relatif dekat sehingga memerlukan pengawasan dan pengaturan kecepatan yang baik.
ATP sebagai sistem kendali otomatis membutuhkan pengembangan perangkat lunak (software) yang mengatur tampilan $\mathrm{MMI}$, kendali otomatis untuk mengatur kecepatan kereta dan lain-lain. Untuk mengembangkan software tersebut beberapa kondisi perlu mendapat perhatian antara lain sebagai berikut:

\section{Kondisi Lintasan (Track)}

Di Indonesia lintasan jalan kereta api dibagi menjadi beberapa bagian yang disebut blok sinyal. Blok sinyal yang digunakan adalah blok tetap (fixed block), dimana jalan rel dibagi menjadi beberapa bagian jalan rel, yang dipisahkan oleh sinyal. Panjang blok dirancang untuk memungkinkan frekuensi perjalanan kereta sesuai keperluan. Lintasan yang tidak begitu sibuk mungkin memiliki panjang blok beberapa kilometer, tapi lintasan kereta komuter yang sibuk seperti lintas Jakarta Kota - Bogor mungkin memiliki panjang blok hanya beberapa ratus meter.

Kereta api tidak diizinkan untuk memasuki blok sampai sinyal menunjukkan bahwa kereta dapat melanjutkan perjalanan. Dalam kebanyakan kasus, kereta api tidak bisa masuk blok sampai tidak hanya blok itu sendiri yang tidak berisi kereta lain, tapi juga satu blok didepannya kosong ${ }^{4}$.

Gambar 1 menunjukkan kondisi beberapa blok di lintas Jabodetabek, yaitu lintas antara Stasiun Pasar Minggu sampai dengan Stasiun Depok baru.

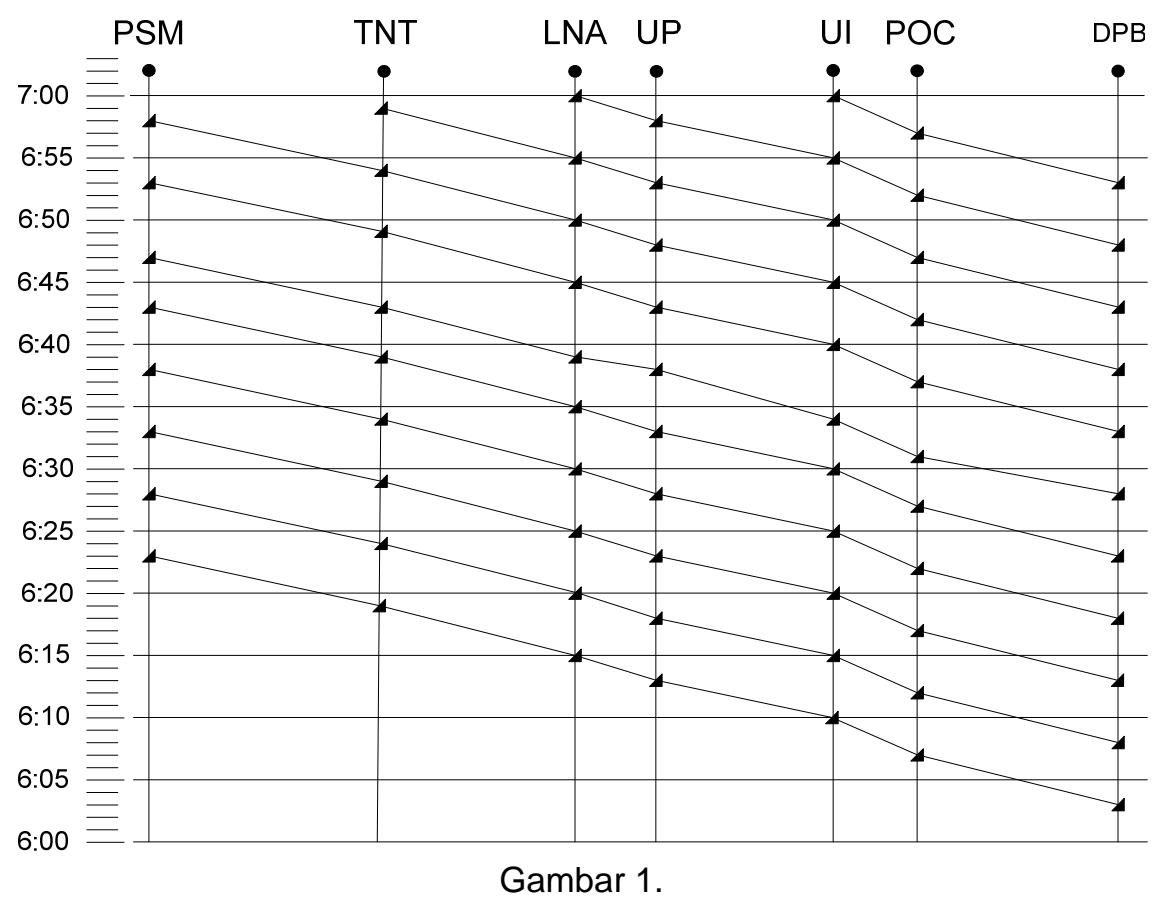


Pada Gambar 1 terlihat bahwa apabila perjalanan kereta (KRL) sesuai dengan jadwal maka paling kurang satu blok di depan setiap kereta adalah blok kosong, bahkan beberapa blok kosong, sehingga frekwensi pemberangkatan kereta masih bisa ditingkatkan dengan aman. Pada kondisi tersebut di atas kemungkinan suatu rangkaian kereta bertabrakan dengan rangkaian kereta lainnya yang ada didepannya sangat kecil bahkan tidak akan terjadi selama sistem persinyalan berfungsi dengan baik. Dengan demikian fungsi ATP yang dibutuhkan adalah fungsi pengendalian kecepatan dan pengereman sehingga kereta tidak dipacu melebihi kecepatan yang diizinkan, dan tidak menabrak sinyal merah. Dalam kondisi tersebut sistem ATP yang dibutuhkan adalah sistem ATP intermitten.

\section{Pengaturan Kecepatan}

Sesungguhnya pengendalian kecepatan KRL dilakukan dengan mengatur besarnya energi yang digunakan untuk menggerakkan atau menjalankan KRL itu sendiri. Pada umumnya saat KRL mulai bergerak, sebelum mencapai kecepatan stabil, energi sebagian besar digunakan untuk memberi akselerasi pada KRL dari keadaan diam sampai ke kecepatan stabil. Sedang pada saat KRL sudah pada keadaan stabil sebagian besar energi digunakan untuk mengatasi resistance KRL. Dengan demikian gaya yang diberikan, sesuai dengan peralatan kendali yang dimiliki 5). KRL yang pernah dibangun di Indonesia pengaturan energinya dirancang seperti terlihat pada Gambar 2.

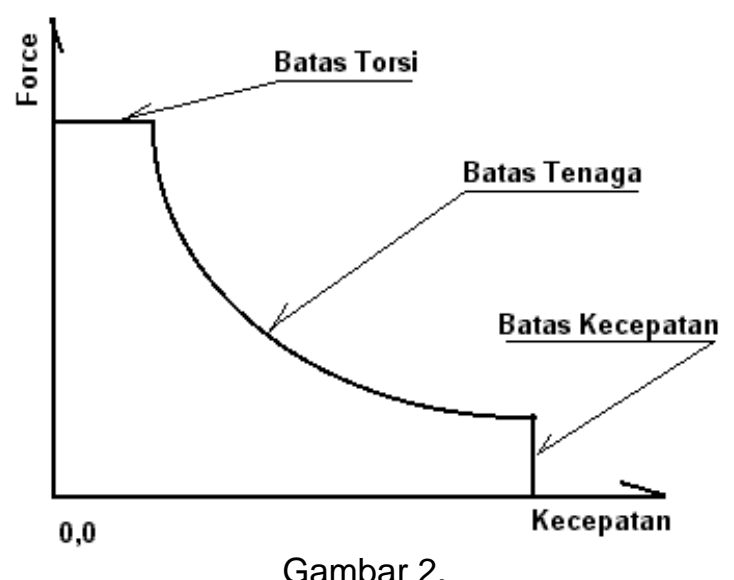

Gaya yang dibutuhkan untuk menggerakkan $\mathrm{KRL}$

Pada Gambar 2 terlihat bahwa, pada mulanya, KRL bergerak, dengan gaya maksimum dan konstan sampai kecepatan tertentu. Hal ini memberikan percepatan yang konstan pula, akibatnya kecepatan KRL pada interval waktu tersebut bertambah dengan pertambahan linier. Periode waktu selanjutnya gaya yang diberikan dikurangi secara bertahap dalam bentuk pengurangan eksponensial, sehingga percepatan KRL juga berkurang secara eksponensial. Akibatnya kecepatan bertambah secara eksponensial menuju ke kecepatan tetap seperti terlihat pada Gambar 3.

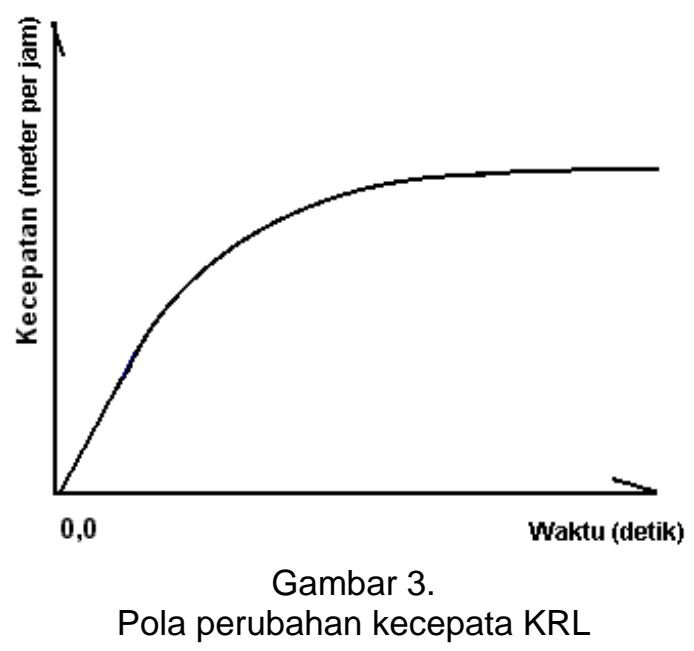

\section{HASIL DAN PEMBAHASAN}

Hasil pengujian akselerasi satu KRL yang baru selesai dibangun yaitu kemampuan akselerasinya ditunjukkan pada Gambar 4.

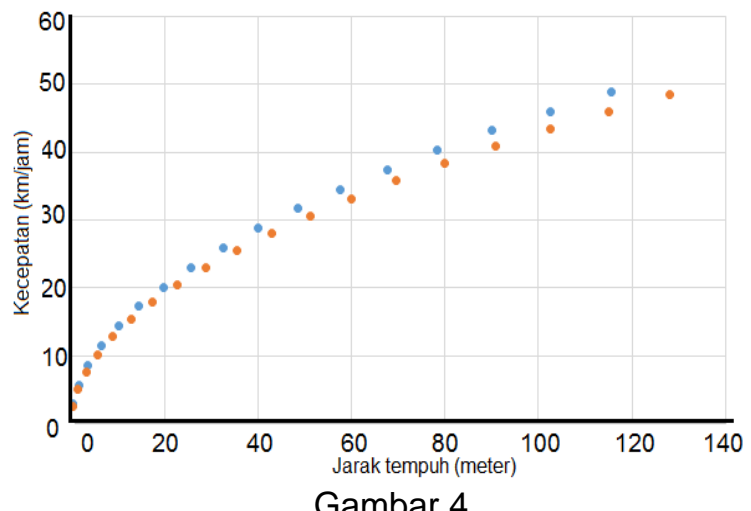

Hasil uji akselerasi KRL.

Gambar 4 memperlihatkan hasil uji akselerasi satu KRL yang baru selesai dibangun dengan cara KRL dijalankan dari posisi diam (kecepatan $0 \mathrm{~km} / \mathrm{jam}$ ) sampai mencapai kecepatan $50 \mathrm{~km} / \mathrm{jam}$. Dari pengujian tersebut diperoleh bahwa KRL tersebut didesain dengan akselerasi 0,8 meter/detik ${ }^{2}$. Grafik warna biru (bagian atas) adalah grafik sesuai desain, sedangkan grafik warna coklat (bagian bawah) adalah grafik hasil pengujian. Grafik akselerasi KRL yang 
diperlihatkan pada Gambar 4 tersebut adalah grafik fungsi kecepatan terhadap jarak tempuh yang dibutuhkan untuk pengawasan/pengendalian kecepatan oleh ATP ${ }^{6)}$.

Berlawanan dengan percepatan (akselerasi) tersebut, perlambatan (deselerasi) pada saat pengereman juga diperlukan. Prinsip umumnya adalah bahwa kereta api dalam semua kondisi harus dapat berhenti satu blok sebelum blok yang berisi kereta pada blok di depannya. Kereta baru dapat melanjutkan perjalanannya apabila blok berikutnya menjadi kosong dan terdeteksi bebas.

Sistem ATP perlu mengetahui sampai berapa kecepatan kereta api dapat dipacu pada daerah tertentu agar bisa berhenti pada daerah dimana blok didepannya tidak bisa dimasuki. Untuk melakukan hal tersebut perlu pengetahuan tentang kurva pengereman, yang memberikan indikasi pola deselerasi yang praktis. Sistem ATP akan memastikan bahwa kereta berjalan dalam batasan kurva pengereman yang relevan. Apabila tidak dilakukan, maka ATP akan memberi peringatan kepada masinis bahwa kereta berjalan lebih cepat dari kurva pengereman, dan akan melakukan intervensi jika kereta tetap menabrak sinyal berhenti (lampu merah) ${ }^{7}$.

Hasil pengujian pengereman satu KRL yang baru selesai dibangun yaitu deselerasi pada saat pengereman.ditunjukkan pada gambar 5 .

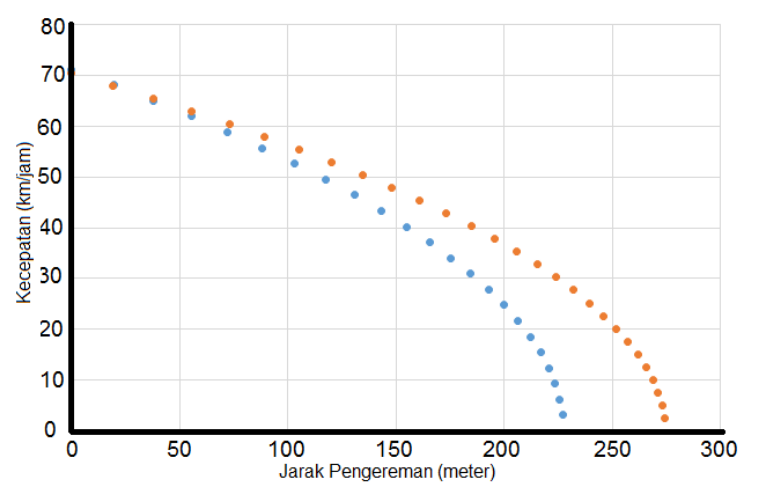

Gambar 5.

Hasil uji pengereman dinamis KRL.

Gambar 5 memperlihatkan hasil uji pengereman dinamis satu KRL yang baru selesai dibangun dengan cara KRL dijalankan sampai mencapai kecepatan $70 \mathrm{~km} / \mathrm{jam}$.
Pada saat kecepatan sudah kontan yaitu $70 \mathrm{~km} / \mathrm{jam}$, dilakukan pengereman sampai mencapai kereta betul-betul berhenti (kecepatan $0 \mathrm{~km} / \mathrm{jam}$ ). Dari pengujian tersebut diperoleh bahwa KRL tersebut didesain dengan perlambatan dinamis 0,86 meter/detik ${ }^{2}$. Grafik warna biru (bagian bawah) adalah grafik sesuai desain, sedangkan grafik warna coklat (bagian atas) adalah grafik hasil pengujian. Grafik deselerasi $\mathrm{KRL}$ yang diperlihatkan pada gambar 5 tersebut adalah grafik fungsi kecepatan terhadap jarak tempuh yang dibutuhkan untuk pengawasan/pengendalian kecepatan oleh ATP ${ }^{9,10)}$.

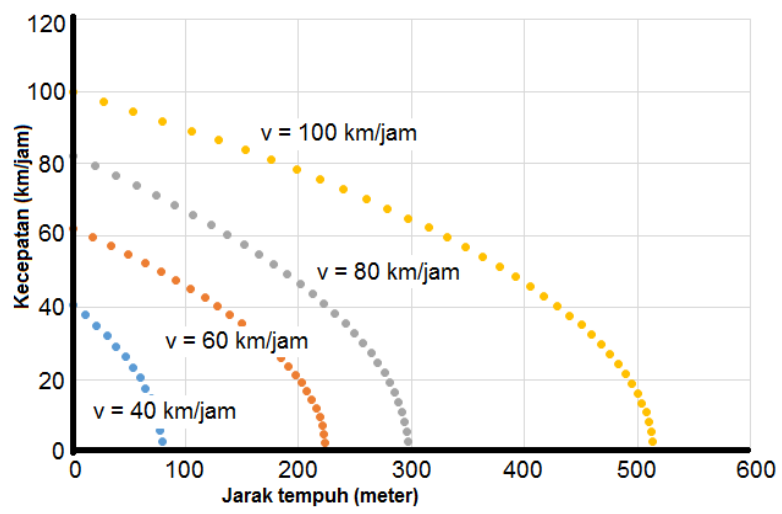

Gambar 6.

Hasil uji pengereman pneumatik KRL.

Gambar 6 memperlihatkan hasil uji pengereman peneumatik (pneumatic braking) satu KRL yang baru selesai dibangun dengan cara KRL dijalankan sampai mencapai beberapa kecepatan yaitu kecepatan 100 $\mathrm{km} / \mathrm{jam}, 80 \mathrm{~km} / \mathrm{jam}, 60 \mathrm{~km} / \mathrm{jam}$ dan 40 $\mathrm{km} / \mathrm{jam}$. Pada saat kecepatan sudah kontan pada masing-masing kecepatan tersebut, dilakukan pengereman pneumatik sampai mencapai kereta betul-betul berhenti (kecepatan $0 \mathrm{~km} / \mathrm{jam}$ ). Dari pengujian tersebut diperoleh bahwa $\mathrm{KRL}$ tersebut mempunyai perlambatan pengereman pneumatk sebagai berikut :

a. Kecepatan $100 \mathrm{~km} / \mathrm{jam}$ perlambatan = $0,75 \mathrm{~m} / \mathrm{det}^{2}$

b. Kecepatan $80 \mathrm{~km} / \mathrm{jam}$ perlambatan $=$ $0,76 \mathrm{~m} /$ det. $^{2}$

c. Kecepatan $60 \mathrm{~km} / \mathrm{jam}$ perlambatan = $0,66 \mathrm{~m} / \mathrm{det}^{2}$

d. Kecepatan $40 \mathrm{~km} / \mathrm{jam}$ perlambatan $=$ $0,81 \mathrm{~m} / \mathrm{de}^{2}$ 


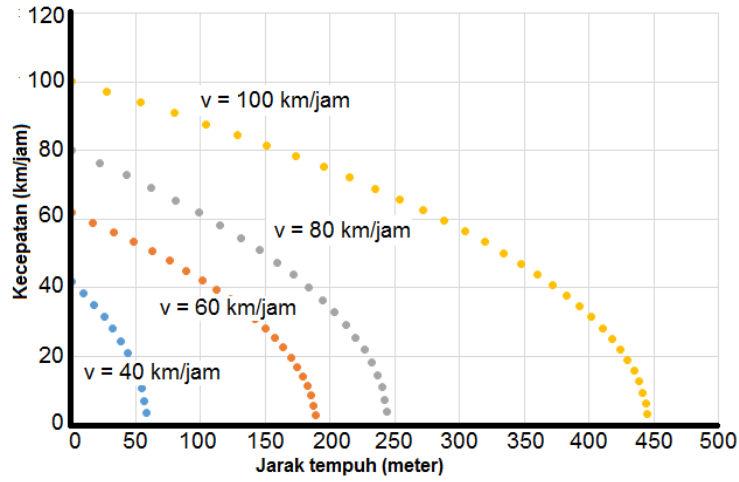

Gambar 7.

Hasil uji pengereman darurat KRL.

Gambar 7 memperlihatkan hasil uji pengereman darurat (emegency braking) satu KRL yang baru selesai dibangun dengan cara KRL dijalankan sampai mencapai beberapa kecepatan yaitu kecepatan $100 \mathrm{~km} / \mathrm{jam}, 80$ $\mathrm{km} / \mathrm{jam}, 60 \mathrm{~km} / \mathrm{jam}$ dan $40 \mathrm{~km} / \mathrm{jam}$. Pada saat kecepatan sudah kontan pada masingmasing kecepatan tersebut, dilakukan pengereman darurat sampai mencapai kereta betul-betul berhenti (kecepatan $0 \mathrm{~km} / \mathrm{jam}$ ). Dari pengujian tersebut diperoleh bahwa KRL tersebut mempunyai perlambatan pengereman darurat sebagai berikut :

a. Kecepatan $100 \mathrm{~km} / \mathrm{jam}$ perlambatan = $0,87 \mathrm{~m} /$ det. $^{2}$

b. Kecepatan $80 \mathrm{~km} / \mathrm{jam}$ perlambatan = $1,01 \mathrm{~m} /$ det. $^{2}$

c. Kecepatan $60 \mathrm{~km} / \mathrm{jam}$ perlambatan = $0,78 \mathrm{~m} /$ det. $^{2}$

d. Kecepatan $40 \mathrm{~km} / \mathrm{jam}$ perlambatan = $0,97 \mathrm{~m} / \mathrm{de}^{2}$

\section{SIMPULAN}

Untuk mendesain sistem keselamatan kereta api otomatis khususnya untuk penerapan pada komuter-line seperti jaringan komuter line di Jakarta-Bogor-Depok-TangerangBekasi (JABODETABEK), yang menggunakan kereta rel listrik (KRL), perlu analisis beberapa hal sebagai dasar pengembangan algoritma sistem kendalinya yaitu kondisi lintasan, akselerasi dan deselerasi KRL yang beroperasi pada lintasan tersebut.

Kondisi lintasan (trek) terutama berkaitan dengan panjang blok, besarnya headway, menunjukkan bahwa dalam kondisi normal kemungkinan terjadinya tumbukan antara kereta dengan kereta sangat kecil. Kondisi tersebut akan berubah apabila kapasitas lintas dinaikkan dengan memperkecil headway.
Hasil uji dinamis KRL berupa akselerasi masing-masing $\mathrm{KRL}$ yang berada pada kisaran 0,8 meter/detik ${ }^{2}$ untuk berbagai kecepatan, deselerasi pengereman dinamis, deselerasi pengereman pneumatik, deselerasi pengereman darurat yang juga pada kisaran perlambatan 0,8 meter/detik ${ }^{2}$, dapat bermanfaat untuk mengembangkan algoritma untuk merancang system kendali kereta sedemikian rupa sehingga kecelakaan akibat kesalahan masinis bisa diminimalkan.

\section{UCAPAN TERIMA KASIH}

Perkenankanlah kami mengucapkan terimakasih kepada Direktorat Jenderal Perkeretaapian Kementerian Perhubungan, PT. KAI (Persero) Bandung, PT. LEN Industri (Persero) yang telah bekerjasama dan memberikan bantuan masukan kepada Perekayasa Pusat Teknologi, Industri, dan Sistem Transportasi (PTIST), Badan Pengkajian dan Penerapan Teknologi (BPPT) dalam melaksanakan Program kajian Sistem Kendali Kereta Api, khususnya kajian pengembangan automatic train protection (ATP).

\section{DAFTAR PUSTAKA}

1. Bao, X., Dong, W., ett all, Design of ATP (Auto Train Protection) Software Architecture Based on Hierarchical Component Model, Proceedings of the 2009 International Symposium on Web Information Systems and Applications (WISA'09), Nanchang, China, 2009.

2. Davies, D., Automatic Train Protection for the Railway Network in Britain -a Study, The Royal Academi of Engineering, London, 2000.

3. Mattalia, A., The effects on operation and capacity on railways deriving from the switching to continous signals and tracing systems (ERTMS), Master Thesis, Div. for Transportation \& Logistics KTH Railway Group, Stockholm - April 2007.

4. Chi-Kang, L., The Minimum Headway of a Rail Transit Line, Joumal of the Eastem Asia Society for Transportation Studies, Vol. 2, No. 1, Autumn, 1997.

5. Kamar, S,. Rancang Bangun Instrumentasi FUDIKA untuk Pengujian Pengereman Dinamis Kereta Api, Pusat Pengkajian dan Penerapan Teknologi Industri dan Sistem Transportasi, Deputi Bidang TIRBR, BPPT. 2009. 
6. Parkinson, T., Fisher, I., Rail Transit Capacity, Transportation Research Board, National Academy Press, Washington DC, 1966.

7. Chen, R., Guo, J., Development of the new CBTC system simulation and performance analysis, WIT Transactions on The Built Environment, Vol 114, WIT Press, China, 2010.

8. Lozano, J, A., et al., Reliability and Safety in Railway, Universidad Politécnica de Madrid, Spain. 2012.
9. Husain, A, A., Dynamic Braking Control for Accurate Train Braking Distance Estimation under Different Operating Conditions, Dissertation submitted to the faculty of the Virginia Polytechnic Institute and State University in partial fulfillment of the requirements for the degree of Doctor of Philosophy In Mechanical Engineering, Blacksburg, VA, USA, February 20, 2013.

10. Presciani, P., et al., Development of a Braking Model for Speed Supervision Systems, World Cong. Railways Research 2001, Coln, Germany, 2001. 